\title{
SIMULASI TRANSPOR BERKAS ION DALAM AKSELERATOR SAMES J 2.5
}

\author{
Sigit Hariyanto \\ Pusat Penelitian dan Pengembangan Teknologi Maju - BATAN
}

\begin{abstract}
ABSTRAK
SIMULASI TRANSPOR BERKAS ION DALAM AKSELERATOR SAMES J 2.5. Telah dilakukan simulasi transpor berkas ion dalam akselerator SAMES j. 2.5 dengan program partikel berkas optik laboratory versi 1.1.1. Berkas ion untuk eksperimen APNC digunakan ion deuterium, keluar dari pemercepat tenaga $150 \mathrm{keV}$, amplop berkas dengan ruji ke arah horisontal $X=1,923 \mathrm{~cm}$, sudut kemiringan $X^{\prime}=0,471 \mathrm{mRad}$ dan ruji ke arah vertikal $Y=1,973 \mathrm{~cm}$, sudut kemiringan $Y^{\prime}=0,4538$ mRad. Keluaran berkas dari tabung pemercepat dilewatkan pada pemokus kuadrapol listrik, pemandu berkas dan ke target. Pembatasa peledaran berkas dipasang program "fitting" pada ujung pemandu dan target dengan ruji ke arah $X, Y$ adalah $15 \mathrm{~mm}$ dan $12 \mathrm{~mm}$ Hasil simulasi program menunjukkan bahwa amplop berkas ke arah $X, Y$ pada ujung pemandu adalah 13,16 $\mathrm{mm}$ dan $17 \mathrm{~mm}$, sedangkan pada target ruji berkas ke arah $X, Y$ adalah 11,6 mm dan 13,4 mm. Koefisien kuadrapol listrik diperoleh 59,089 dan-74,6785 atau kalau dihitung tegangan listrik yang harus diberikan 2,77kV dan -3,5 kV. Untuk eksperimen PIXE keluaran berkas ion hydrogen dari tabung pemercepat dilewatkan pada kuadrapol listrik, pembelok magnet, kuadrapol magnet dan ke target. "Fitting” amplop berkas sebelum kuadrapol dengan ruji ke arah $X$ dan $Y 10 \mathrm{~mm}$ dan pada target 1,5mm. Hasil perhitungan program diperoleh koefisien kuadrapol listrik 69,3056 dan-73,7274 atau pada tegangan 6,49 kV dan $-6,22 k V$. Sedangkan besarnya medan magnet pada kuadrapol magnet adalah 0,51kG. dan $-0,57 k G$.
\end{abstract}

\begin{abstract}
SIMULATION OF ION BEAM TRANSPORT IN SAMES J 2.5 ACCELERATOR. Simulation of ion beam transport in J.2.5 accelerator using particle beam optics laboratory program version 1.1.1. has been carried out. The ion beam of APNC experiment were deuterium ion, output energy accelerator of $150 \mathrm{keV}$, radius of beam envelope in horizontally $X=1.923 \mathrm{~cm}$, beam divergence of $X^{\prime}=0.471 \mathrm{mRad}$ and radius of beam envelope in vertically $Y=1.973 \mathrm{~cm}$, beam divergence of $Y^{\prime}=0.454 \mathrm{mRad}$. The beam output of accelerator tube passing through a electrostatic quadrupole, beam guide and the target. The beam spread limited is entered "fitting" program and the target at the end beam guide and the target with radius in $X, Y$ direction of $15 \mathrm{~mm}$ and $12 \mathrm{~mm}$. The result of simulation program has shown that beam envelope in $X, Y$ direction at the end beam guide are 13,6 $\mathrm{mm}$ and $17 \mathrm{~mm}$, beam radius of the target in $X, Y$ direction are $11.6 \mathrm{~mm}$ and 13,4 $\mathrm{mm}$. Electrostatic quadrupole coefficient are 59.089 and $-74,678$, if electric voltage calculation must be delivered $2.77 \mathrm{kV}$ and $-3.5 \mathrm{kV}$. The hydrogen ion beam for PIXE experiment of accelerator tube passing trough in electrostatic quadrupole, bending magnet, magnetic quadrupole and target. The "fitting" program before magnetic quadrupole and target with radius of beam in $X, Y$ direction are $10 \mathrm{~mm}$ and $1,5 \mathrm{~mm}$. The result of calculation program has shown that quadrupole coefficient are 69.3056 and $-73,7274$, the electric voltage are $6.49 \mathrm{kV}$ and $-6.22 \mathrm{kV}$. The magnitude magnetic field of magnetic quadrupole are $0.51 \mathrm{kG}$ and $-0,57 \mathrm{kG}$.
\end{abstract}

\section{PENDAHULUAN}

$\mathrm{D}$ alam perencanaan pengembangan akselerator Sames J 2.5 atau generator netron di P3TM-Batan diharapkan selain dimanfaatkan untuk analisa pengaktipan netron cepat (APNC), dapat juga dimanfaatkan untuk eksperimen yang lain yaitu PIXE energi rendah. Hal ini memerlukan sistem transpor berkas dari sumber ion melewati pemercepat dan terus ke tempat dimana eksperimen mau dilaksanakan. Untuk eksperimen APNC dilakukan dengan memanfaatkan peralatan/ komponen yang sudah ada serta memperpanjang tabung hanyut (drift tube) 
dan menggeser penempatan kedudukan tritium target. Sedangkan pada eksperimen PIXE, keluaran berkas ion dari pemercepat dibelokkan lebih dulu untuk untuk diarahkan ke target. Untuk itu diperlukan perencanaan penempatan berbagai peralatan transpor berkas seperti pembelok (bending magnet) atau deflektor, pemokus (kwadrapol magnet atau elektrostatis), tabung hanyut, pemantau profil berkas, pemantau arus berkas serta tambahan sistem hampa. Perencanaan pengembangan eksperimen PIXE memerlukan perhitungan simulasi keadaan/kualitas berkas sepanjang perjalanan berkas ion, sehingga dapat mencapai target di tempat eksperimen pada keadaan dan kualitas yang diinginkan. Simulasi ini akan dicoba dilakukan dengan program transport PBO (Particle Beam Optics) yang memang sudah dikembangkan untuk tujuan transpor berkas. ${ }^{(1)}$

Dalam makalah ini dilaporkan hasil simulasi yang telah dilakukan untuk berkas deuterium, yang dipercepat dengan tegangan $150 \mathrm{kV}$. Dari sumber ion RF. Untuk simulasi ini digunakan model tataletak akselerator $\mathrm{J}$ 2.5 buatan SAMES dan menyesuaikan pemandu berkas yang melewati pembelok magnet dengan dimensi lebih kecil dari jarak kutup magnetnya (Gambar 1). Amplop berkas ion yang melewati peralatan akselerator dijaga tidak menumbuk dinding-dindingnya dan diameter berkas yang mengenai target dapat diperoleh sesuai dengan yang diinginkan. Simulasi untuk perancangan PIXE diperlikan tambahan peralatan yaitu pembelok maknet, pemokus kuadrapol magnet yang telah dan sedang dipersiapkan di P3TM.

\section{DASAR TEORI}

Suatu berkas partikel yang bergerak dalam garis tranpoortasi berkas melalui sistem statis maupun sistem medan magnet maupun elektrostatis dapat disederhanakan dengan proses perkalian matriks.

$$
\mathrm{X}(1)=\mathrm{R} \mathrm{X}(0)
$$

Subskrip 0 dan 1 menunjukkan masuk dan keluarnya berkas ke masing-masing peralatan atau komponen sistem akselerator. $R$ adalah matriks pengiriman (matrix $\mathrm{R}$ ) dengan elemen 6x6 untuk orde pertama, merupakan persamaan gerak partikel yang melalui peralatanatau komponen akselerator. Beberapa komponen akselerator yang digunakan untuk eksperimen antara lain : tabung hanyut, lensa lensa pemokus, pembelok magnet, kuadrapol magnetbdan sebagainya. Secara umum matriks R untuk semua komponen akselerator merupakan perkalian masing-masing matriks ${ }^{(2)}$;

$$
\mathrm{R} \text { total }=\mathrm{R}(\mathrm{n}) \ldots . . \mathrm{R}(3) \mathrm{R}(2) \mathrm{R}(1)
$$

Berkas partikel dalam garis perjalanan kalau diproyeksikan ke bidang horisontal maupun vertical berbentuk elips dengan arah yang berbeda. Teorema Liouville sangat berguna untuk menggambarkan berkas dalam ruang fase. Bila kita tahu luas yang diduduki oleh partikel-partikel dalam ruang fase pada awal dari garis peralanan berkas, maka kita dapat menentukan lokasi dan distribusi berkas pada tiap tempat yang lain sepanjang garis perjalanan, tanpa harus menghitung trayektory dari masing-masing partikel. Elips yang membatasi semua partikel dari berkas dalam ruang fase disebut elips fase.

Persamaan elips dalam dimensi $n$ dituliskan dalam bentuk matriks sebagai berikut $^{(2,3)}$ :

$$
X(0)^{\mathrm{T}} \sigma(0)^{-1} \mathrm{X}(0)=1
$$

Dengan $X(0)^{T}$ adalah tranpose dari koordinat vector matriks kolom berkas $\mathrm{X}(0)$ dan $\sigma(0)$ matriks simetri merupakan bilangan nyata positif, kalau dituliskan dalam 2 dimensi (x,X') arah horizontal matriks $\sigma$ :

$$
\begin{aligned}
& \sigma_{22}=\left[\begin{array}{ll}
\sigma_{11} & \sigma_{21} \\
\sigma_{21} & \sigma_{22}
\end{array}\right] \text { inversnya } \sigma^{-1}=1 / \varepsilon_{x}^{2}\left[\begin{array}{cc}
\sigma_{22} & \sigma_{221} \\
-\sigma_{21} & \sigma_{11}
\end{array}\right] \\
& \text { dengan } \varepsilon_{x}^{2}=\text { determinan } \sigma \\
& \text { matriks kolom berkas : }
\end{aligned}
$$




$$
X=\left[\begin{array}{c}
x \\
x^{\prime}
\end{array}\right] \text { dan } X^{-T}=\left(\begin{array}{ll}
x & x^{\prime}
\end{array}\right)
$$

Penjabaran persamaan matriks $X^{\mathrm{T}} \sigma-1 \mathrm{X}=$ 1 adalah bentuk persamaan elips :

$$
\sigma_{22} X^{2}-2 \sigma_{21} X^{\prime}+\sigma_{11} X^{, 2}=\varepsilon_{x}^{2}
$$$$
=\operatorname{det} \sigma
$$

Luas elips adalah :

$\mathrm{A}=\pi \varepsilon_{\mathrm{X}}=\pi(\text { det } \sigma)^{1 / 2}=\pi \mathrm{X}_{\mathrm{mak}} \mathrm{X}^{\prime}{ }_{\text {int }}=\pi$ $\mathrm{X}_{\text {int }} \mathrm{X}_{\text {mak }}^{\prime}, \varepsilon_{\mathrm{X}}=$ emitansi

Elips fase pada bidang (X, $\left.X^{\prime}\right)$ ditunjukkan pada Gambar 1 dengan masing-masing elemen matriks $\sigma$.

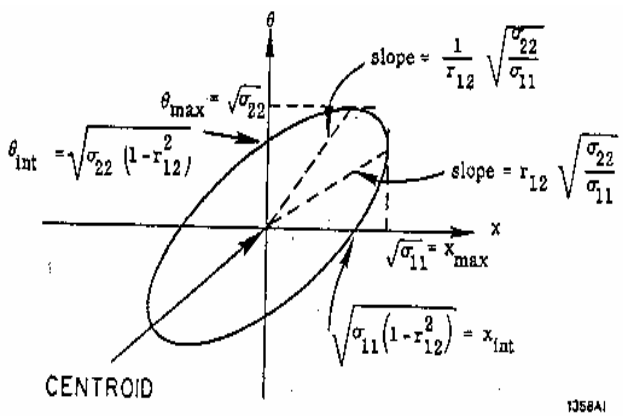

Gambar Elips fase pada bidang (X,X')

Orientasi dari elips adalah korelasi antara $\mathrm{X}$ dan X', yang besarnya tergantung $\sigma_{\mathrm{ii}}$

$$
r_{12}=r_{21}=\frac{\sigma_{21}}{\sqrt{\left(\sigma_{11} \sigma_{22}\right)}}
$$

berkas partikel setelah melalui sistem komponen akselerator, transformasi berkas matriksnya ditunjukkan pada persamaan 1 yaitu $X(1)=R \quad X(0)$. Kombinasi matriks tersebut dengan persamaan berkas matriks elips, dan dengan menggunakan matriks satuan $R R^{-1}=I$, diperoleh :

$X(0)^{T}=\frac{\left(R^{T} R^{T-1}\right)}{I} \sigma(0)^{-1} \frac{\left(R^{T} R^{T-1}\right)}{I} X(0)=1$ atau

$\left[\begin{array}{ll}\mathrm{R} X(0)\end{array}\right]^{\mathrm{T}}\left[\begin{array}{ll}\mathrm{R} \sigma(0) & \mathrm{R}^{\mathrm{T}}\end{array}\right]^{-1} \quad[\mathrm{R} \mathrm{X}(0)]=1$ Diperoleh elips baru setelah transformasi menjadi :

$$
\begin{array}{ll} 
& \mathrm{X}(1)^{\mathrm{T}} \sigma(1)^{-1} \mathrm{X}(1)=1 \\
\text { Dengan } & : \quad \sigma(1)=\mathrm{R} \sigma(0) \mathrm{R}^{\mathrm{T}}
\end{array}
$$

Persamaan diatas merupakan matriks sigma pada ujung garis transport berkas dihubung-kan dengan awal bidang berkas.

Arti fisis element matriks $\sqrt{\sigma_{i i}}$ sebagai berikut :

$\sqrt{\sigma_{11}}=\mathrm{X}_{\mathrm{mak}}=$ setengah lebar maksimum amprlop berkas pada bidang $\mathrm{X}$

$\sqrt{\sigma_{22}}=X^{\prime}=$ setengah sudut divergensi amplop berkas pada bidang $\mathrm{X}$

$\sqrt{\sigma_{33}}=\mathrm{Y}_{\mathrm{mak}}=$ setengah tinggi maksimum amplop berkas pada bidang $\mathrm{Y}$

$\sqrt{\sigma_{44}}=\mathrm{Y}^{\prime}=$ setengah sudut divergensi amplop berkas pada bidang $\mathrm{Y}$

$\sqrt{\sigma_{55}}=1=$ penyebaran arah longitudinal berkas

$\sqrt{\sigma_{66}}=\delta=\Delta \mathrm{p} / \mathrm{p}=$ pergeseran momentum yang ditransmisikan sistem

Berkas partikel di dalam transport berkas proyeksinya merupakan bentuk elips, dapat juga dituliskan dalam bentuk parameter Twiss $\alpha, \beta, \gamma$

$$
\gamma_{\mathrm{x}} \mathrm{x}^{2}+2 \alpha_{\mathrm{x}} \mathrm{x} \mathrm{x}^{\prime}+\beta_{\mathrm{x}} \mathrm{x}^{2}=\varepsilon_{\mathrm{x}}
$$

masing masing elemen pada persamaan elips diatas dapat dinyatakan dalam bentuk matriks sigma dengan,

$\gamma_{\mathrm{x}}=\sigma_{22} / \varepsilon_{\mathrm{x}}, \quad \beta_{\mathrm{x}}=\sigma_{11} / \varepsilon_{\mathrm{x}}, \quad \alpha_{\mathrm{x}}=-\sigma_{12} / \varepsilon_{\mathrm{x}}$.

Parameter twiss alpha, beta, dan gamma juga merupakan parameter courant-syder, Gambar 2 ditunjukka elips fase pada bidang horizontal dengan twiss parameter. 


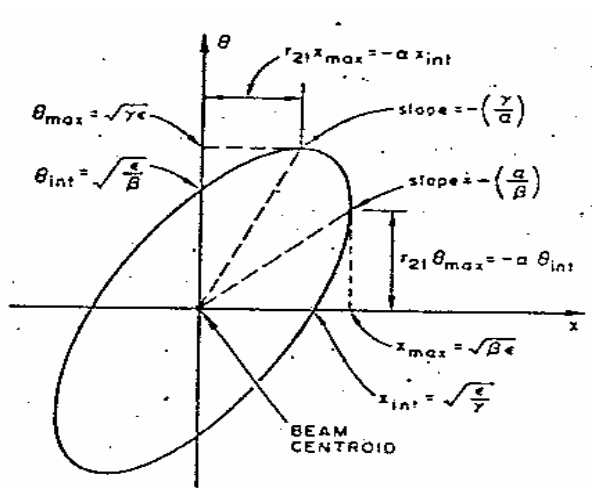

Gambar 2. Fase elips dengan twiss parameter

\section{METODOLOGI DAN TATA KERJA}

Alur berkas yang akan disimulasikan dengan program PBO tata letaknya seperti ditunjukkan pada Gambar 3. Dalam program ini tidak menggunakan kode seperti pada program transport, tetapi mengambil slide komponen akselerator yang ada dalam menu program serta mengurutkannya seperti pada tataletak diatas. Dari gambar tersebut terdiri dari dua ekesperimen yaitu ion deuterium yang ditumbukkan ke tritium target sehingga terjadi hamburan netron cepat dimanfaatkan untuk eksperimen APNC. Sedangkan eksperimen yang kedua proton dari pemercepat dibelokkan dikenakan ke target untuk analisis dengan PIXE energi rendah.

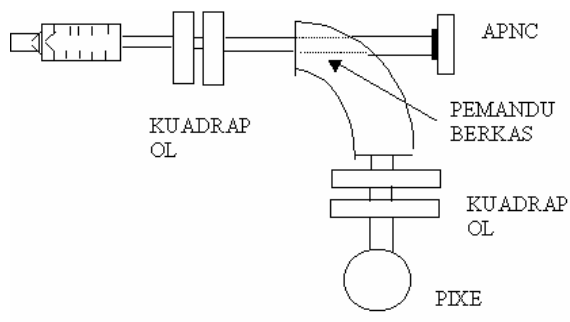

Gambar 3. Tata letak akselerator J25

Ukuran diameter berkas ion pada keluaran tabung pemercepat diukur dengan menggunakan sepasang rotating probe dipasang dengan posisi horisontal dan vertikal pada jarak $6 \mathrm{~cm}$, sedangkan ruji putaran 2,1 cm. Bentuk sinyal dari berkas ion diamati dengan rotating probe dan penampil sinyal digunakan osiloskop Trio CS-1560 A. Pada saat kawat probe memotong berkas akan diperoleh sinyal pulsa baik pada potongan horisontal maupun vertikal. Apabila dua kali memotong dan pada penampil terlihat tiga sinyal atau lebih, maka akan dapat dicari diameter berkas kearah horisontal (pada sumbu $\mathrm{X}$ ) atau vertikal (sumbu Y) serta penyebaran berkas yang terjadi.

Untuk eksperimen pengaktipan netron menggunakan ion deuterium keluaran pemercepat dengan didukung oleh beberapa peralatan/komponen akselerator antara lain kuadrapol elektrostatis, rotating probe, pengukur arus dan tabung hanyut. Parameter awal secara global yang dimasukkan pada program PBO adalah muatan partikel, massa deuterium , energi pemercepat berkas, arus berkas 0,850 $\mathrm{mA}$ dan loncatan jejak dipasang 0,05 m. Parameter berkas yang dimasukkan dalam program ini baik kearah horisontal maupun vertical adalah setengah pelebaran berkas dan sudut kemiringan. Data tersebut diperoleh dari hasil perhitungan dengan cara mengolah data yang diperoleh dari pengukuran sinyal dengan rotating probe. Program ini akan menghitung sendiri emitansi berkas kearah horizontal maupun vertical. Data berkas dari sumbu axial tersebut dapat juga dikorelasikan langsung oleh program untuk menjadi parameter Twiss berkas ion.

Tabung hanyut merupakan komponen akselerator yang paling sederhana dari peralatan akselerator. Parameter yang perlu dimasukkan adalah panjang tabung hanyut dari titik berkas awal atau setelah keluar dari komponen akselerator sebelumnya. Dengan tidak adanya medan luar yang mempengaruhi berkas ion, maka bentuk elips ruang berkas tidak mengalami perubahan rotasi yang drastis.

Sistem pemokus terdiri dari dua buah kuadrapol elektrostatis saling berkaitan, yang satu berfungsi untuk memfokuskan berkas pada arah tertentu sedangkan yang lain tidak memokuskan, sehingga diperlukan doblet 
atau triplet. Parameter tetap yang dimasukkan dalam program untuk kuadrapol elektrostatis adalah panjang elektroda $6 \mathrm{~cm}$. Terdiri dari 4 buah, diameter lubang $5 \mathrm{~cm}$ dan jarak elektroda 2,5 cm. Parameter variable yang dimasukkan adalah koefisien kuadrapol $K_{1}=k^{2}$, parameter ini amat menentukan tegangan listrik yang diberikan didasarkan pada hubungan ${ }^{(4)}$ :

$$
\mathrm{k}=2 / \mathrm{d}(\mathrm{n} \mathrm{V} / \mathrm{E})^{1 / 2}
$$

Dengan $d$ = diameter lubang,$V=$ tegangan potensial

$n=$ nomor atom muatan ion, $E=$ energi ion

Dengan adanya medan listrik ini, pengaruhnya besar sekali pada bentuk elips berkas, sehingga besarnya dianeter berkas yang dihasilkan mengenai target tergantung dari koefisien kuadrapol.

Untuk eksperimen PIXE peralatan yang ditambahkan adalah magnet pembelok dan pemokus electromagnet, sedangkan ion yang digunakan adalah ion $\mathrm{H}^{+}$. Magnet pembelok disamping sebagai analisator juga membelokkan berkas ion, konstruksinya buatan sendiri dan tinggal menyesuaikan ukuran dimensi untuk dimasukkan dalam program. Parameter yang dimasukkan dalam program adalah sudut belok $90^{\circ}$, ruji kelengkungan $42 \mathrm{~cm}$, jarak kutub 3,2 cm, tabung hanyut sebelum dan sesudah pembelok $19 \mathrm{~cm}$. Berdasar data tersebut program akan menghitung sendiri besarnya medan magnet berdasar pada massa maupun energi ion yang lewat.

Sebelum mencapai chamber PIXE berkas ion perlu difokuskan dulu dengan kuadrapol magnet doblet, sesuai yang telah tersedia. Parameter yang dimasukkan dalam kuadrapol magnet antara lain panjang efektif magnet, ruji lubang kuadrapol, Sedangkan parameter variable adalah medan sangat mempengaruhi bentuk berkas yang keluar dari kuadrapol.

Transport berkas ion yang melalui komponen akselerator berupa amplop berkas dimana lintasan bagian luar tidak dapat membedakan apabila lintasan tersebut melebihi dinding pemandu ion atau melampaui jarak kutub. Oleh karena itu pada posisi berkas yang diinginkan dapat dibatasi dengan program "fitting” yang tersedia. Jika program dijalankan, maka akan menghitung sendiri besarnya parameter variable pada komponen akselerator. Program "fitting" ini untuk membatasi amplop berkas yang melewati dan program akan menghitung variable komponen akselerator yang diinginkan untuk dirubah.

\section{HASIL DAN PEMBAHASAN}

Sebelum memasukkan data komponen peralatan akselerator kedalam program PBO, harus diketahui lebih dahulu karakteristik berkas pada awalnya. Pengukuran profil berkas dengan menggunakan rotating probe pada keluaran tabung pemercepat. Rotating probe terdiri dari 2 buah kawat yang berputar dengan arah horisontal dan vertikal untuk memotong berkas ion sambil mengeluarkan sinyal. Dari hasil pengukuran profil berkas dari kedua sinyal tersebut dapat dihitung diameter berkas dan sudut kemiringan. Diameter berkas pada posisi awal arah horizontal adalah 38,46 mm, sudut kemiringan 0,471 mr. sedangkan pada arah vertical diameter $39,36 \mathrm{~mm}$ dan sudut kemiringan 0,454 mr. ${ }^{(5)}$

Untuk eksperimen APNC, ion yang digunakan adalah deterium, pemercepat 150 $\mathrm{kV}$ dengan menggunakan kuadrapol listrik, sehingga parameter yang divariasi adalah koefisien kuadrapol. Hasil perhitungan program PBO serta transpor berkas komponen akselerator ditunjukkan pada Gambar 4a - 4c. Bentuk tabung hanyut yang lewat pembelok disebut pemandu berkas, mempunyai bentuk dimensi ukuran 3,5 cm x $10 \mathrm{~cm}$. 
(a)

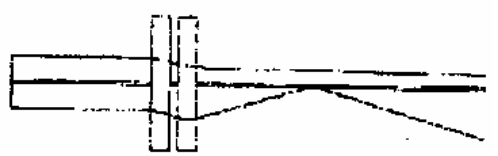

(b)

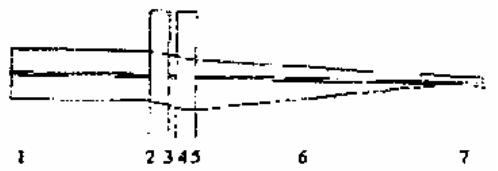

(c)

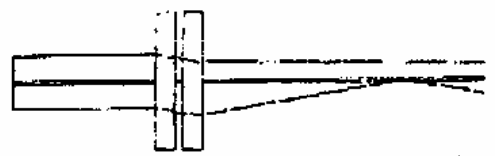

Gambar 4. Transpor berkas untuk eksperimen APNC dengan me "fitting"
; a) pada ujung pemandu,
; b) pada target,
; c) keduanya .

Supaya amplop berkas ion tidak menumbuk dinding, maka perludipasang “fitting” pada program untuk membatasi amplop berkas.

Pada Gambar 4a, ukuran ampelop berkas pada ujung pemandu berkas ion dengan ruji kearah horizontal maupun vertikal adalah $12 \mathrm{~mm}$. Sedangkan pada target ruji ke arah horisontal 10,90 mm dan kearah vertikal 40,9 mm. Hasil tersebut merupakan perhitungan program dengan menggunakan "fitting" pada arah masuk pemandu berkas. Program akan menghitung sendiri dan memperoleh harga koefisien kuadrapol 73,7664 dan -102,0442.

Pada Gambar 4b hasil dari program “fitting” diletakkan pada ujung target dengan batasan ruji ke arah X maupun Y adalah 4 $\mathrm{mm}$. Hasil transpor berkas menunjukkan bahwa ruji berkas ke arah $\mathrm{X}$ adalah 11,49 mm dan ke arah $\mathrm{Y}$ adalah 20,5 mm pada ujung masuk pemandu dan koefisien kuadrapol masing-masing diperoleh 68,9244 dan $-69,4428$.

Pada Gambar 4c hasil program dengan me "fitting" pada ujung pemandu dan target, masing-masing dengan ruji berkas baik kearah X maupun Y adalah 15 mm dan 12 mm. Hasil transpor berkas menunjukkan bahwa ruji berkas pada arah $\mathrm{X}$ dan $\mathrm{Y}$ pada ujung pemandu adalah $13,16 \mathrm{~mm}$ dan $17 \mathrm{~mm}$, sedangkan pada target ruji berkas ke arah $\mathrm{X}$ dan $\mathrm{Y}$ adalah 11,6 mm dan 13,4 mm. Hasil tersebut diperoleh dari menjalankan program dengan harga koefisien kuadrapol listrik masing-masing 59,089 dan-74,6785 . Dari ketiga amplop berkas untuk eksperimen APNC yang paling aman berkas tidak menumbuk dinding pemandu berkas adalah Gambar 4c, hal ini didasarkan pada dimensi pemandu berkas yang tersedia $3,5 \mathrm{~cm} \mathrm{x}$ $10 \mathrm{~cm}$. Apabila dihitung dari persamaan (7) atau dari acuan ${ }^{(5)}$ hubungan antara koefisien kuadrapol dan tegangan kuadrapol untuk kuadrapol listrik, maka untuk koefisien kuadrapol $\mathrm{K}_{1}=$ 59,0896 diperoleh tegangan kuadrapol 2,77 kV., sedangkan pada koefisien kuadrapol $\mathrm{K}_{1}=-74,6785$ diperoleh tegangan kuadrapol - 3,5 kV.

(a)

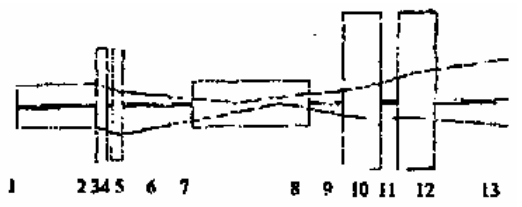

(b)

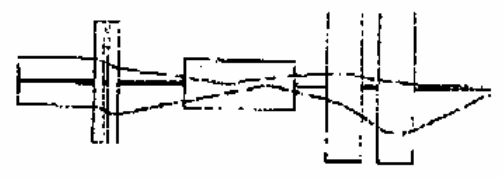

(c)

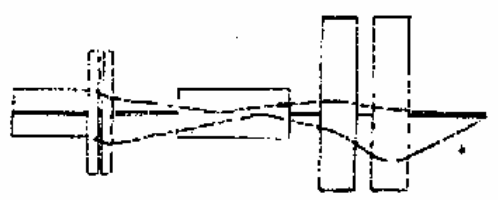

Gambar 5. Transpor berkas untuk eksperimen PIXE

Untuk eksperimen PIXE ion yang digunakan adalah proton dengan tegangan pemercepat $150 \mathrm{kV}$. menggunakan peralatan pemokus kuadrapol listrik sebelum pembelok magnet $90^{\circ}$ dan kuadrapol magnet sesudah pembelok. Parameter yang memungkinkan divariasi adalah koefisien kuadrapol untuk kuadrapol listrik dan besarnya medan magnet untuk kuadrapol magnet. Hasil perhitungan program PBO 
serta transpor berkas ion pada komponen akselerator untuk eksperimen PIXE ditunjukkan pada Gambar 5.

Pada Gambar 5a amplop berkas yang di “fitting” pada masukan kuadrapol magnet dengan ruji ke arah $\mathrm{X}$ dan $\mathrm{Y}$ adalah $10 \mathrm{~mm}$ dan parameter yang dibuat variabel adalah koefisien kuadrapol listrik. Hasil perhitungan program ternyata amplop berkas yang keluar kudrapol magnet dengan ruji ke $\mathrm{X}$ dan ke $\mathrm{Y}$ adalah 35,49 mm dan 22,36 mm, besarnya koefisien kuadrapol adalah 69,3056 dan -73,7279. Ampelop berkas ini melebihi batas dinding tabung hanyut yang mempunyai diameter $50 \mathrm{~mm}$ dalam kuadrapol magnet. Kalau dihitung besarnya tegangan yang harus diberikan pada kuadrapol listrik adalah 6,49 kV.dan -6,92 $\mathrm{kV}$, harga ini kemudian dimasukkan sebagai harga tetap. Pada Gambar 5b, amplop berkas yang di "fitting" pada keluaran berkas kuadrapol magnet atau yang mengenai target dengan ruji ke arah $\mathrm{X}$ dan $\mathrm{Y}$ adalah bervariasi. Untuk ruji 1,5 mm dan setelah menjalankan program diperoleh besarnya medan magnet $0,5010 \mathrm{kG}$. dan $-0,5786 \mathrm{kG}$. Sedangkan untuk "fitting” dengan ruji $1 \mathrm{~mm}$ (Gambar 5c), hasil yang diperoleh besarnya medan magnet adalah 0,5053 kG dan -0,5833 kG, dan amplop berkas pada target dengan ruji ke arah $\mathrm{X}$ dan $\mathrm{Y}$ adalah 1,3 mm dan $1 \mathrm{~mm}$. Hal ini menunjukkan bahwa “fitting" pada target dengan ruji $1 \mathrm{~mm}$ merupakan batas kemampuan magnet kuadrapol pada susunan diatas mampu untuk memokuskan amplop berkas. Untuk lebih dapat fokus lagi perlu diupayakan lainnya seperti diberi diafragma setelah kuadrapol magnet. Data amplop berkas pada setiap komponen akselerator untuk susunan eksperimen APNC maupun susunan eksperimen PIXE ditunjukkan pada lampiran 1. Data tersebut berupa pelebaran berkas kearah horizontal maupun vertical dan parameter alpha dan beta Twiss. Sedangkan pada lampiran 2 ditunjukkan bentuk akhir dari elips fase amplop berkas pada bidang $\mathrm{X}$ dan Y dari hasil program Gambar 4c dan 5b.

\section{KESIMPULAN}

Simulasi transpor berkas untuk eksperimen APNC dilakukan pada tegangan pemercepat $150 \mathrm{kV}$, arus 0,850 mA menggunakan ion deuterium. Hasil perhitungan program dengan me "fitting" pada ujung pemandu, tempat target, serta ujung pemandu dan target dapat disimpulkan bahwa pilihan terakhir merupakan pilihan yang paling tepat dibandingkan dimensi pemandu yang tersedia $35 \mathrm{~mm} \times 100 \mathrm{~mm}$.

Dengan me “fitting” ujung pemandu 15 mm dan target $12 \mathrm{~mm}$, amplop berkas pada target ke arah X dan Y adalah 11,63mm dan 13,36 mm, dengan tegangan pada kuadrapol listrik $2,77 \mathrm{kV}$ dan $3,5 \mathrm{kV}$.

Simulasi transpor berkas untuk eksperimen PIXE dilakukan pada tegangan pemercepat $150 \mathrm{kV}$, arus 0,850 mA menggunakan hidrogen. Hasil perhitungan program me "fitting" pada masukan kuadrapol magnet dengan ruji $10 \mathrm{~mm}$, diperoleh koefisien kuadrapol 69,3056 $\mathrm{m}^{-2}$ dan - 73,7274 $\mathrm{m}^{-2}$ atau pada tegangan kuadrapol listrik 6,49 kV dan - 6,92 kV dan dipakai sebagai parameter tetap.

Dengan me "fitting" baervariasi antara lain pada target pixe dengan ruji $1 \mathrm{~mm}$, amplop berkas ke arah $\mathrm{X}$ dan $\mathrm{Y}$ pada target adalah $1,3 \mathrm{~mm}$ dan $1 \mathrm{~mm}$. Hal ini merupakan batas kemampuan magnet kuadrapol.

\section{UCAPAN TERIMA KASIH}

Dengan selesainya makalah ini, kami ucapkan terima kasih kepada staf kelompok pengembangan atas bantuan dan partisipasi dalam penelitian ini.

\section{DAFTAR PUSTAKA}

1. George Gillespie, dkk., Outline of Particle Beam Optics Laboratory Tutorial Version 1.1.1, G.H. Gillespie Associates Inc. 1998.

2. Browm, KL., dkk., Transport a Computer Program for Designing Charged Particle Beam Transport 
Systems, CERN Report 73-16, Geneva (1973).

3. Wiedner C.A, Beam transport system, accelerator school, Center for Research and Development of Advanced Technology, 2003.

4. Shiroh KIKUCHI, Suehiro TAKEUCHI, A Computer Code "Beam" for the Ion Optics Calculation of the JAERI Accelerator System, JAERI 1987..
5. Sigit Hariyanto dkk., Simulasi Alir Berkas Partikel Akselerator J 2.5 Untuk Eksperimen Pixe Energi Rendah, Prosiding PPI, P3TM, Yogyakarta, 2002.

\section{LAMPIRAN}

Data amplop transpor berkas untuk susunan eksperimen APNC :

Data Gambar 4a.

$\begin{array}{rrr}\text { No. } & \text { LENGTH } & \text { XBEAM } \\ 1 . & .00000 & 19.23001 \\ 2 . & .45000 & 19.19683 \\ 3 . & .51000 & 16.69974 \\ 4 . & .53500 & 14.66686 \\ 5 . & .59500 & 12.26129 \\ 6 . & .79500 & 12.00000 \\ 7 . & 1.58500 & 10.98727\end{array}$

YBEAM
19.71301
19.70407
22.37770
24.65526
25.40110
12.00000
40.93688

ALPHAX

.16400

.15283

151.81100

133.44390

1.79753

1.74720

1.54839

BETAX

41.35590

41.21333

31.17751

24.06950

16.81321

16.10426

13.50075

Data Gambar 4b :

$\begin{array}{rrr}\text { No. } & \text { LENGTH } & \text { XBEAM } \\ 1 . & .00000 & 19.23001 \\ 2 . & .45000 & 19.19683 \\ \text { 3. } & .51000 & 17.12574 \\ 4 . & .53500 & 15.43327 \\ 5 . & .59500 & 13.16968 \\ 6 . & .79500 & 11.30655 \\ 7 . & 1.58500 & 4.00002\end{array}$

\section{YBEAM \\ 19.71301 \\ 19.70407 \\ 21.90361 \\ 23.77037 \\ 25.15644 \\ 19.26951 \\ 4.00000}

ALPHAX

.16400

.15283

129.53020

116.87080

13.72631

11.77333

4.05879
BETAX

41.35590

41.21333

32.76716

26.64314

19.39658

14.29674

1.78938

Data Gambar 4c.

$\begin{array}{rrr}\text { No. } & \text { LENGTH } & \text { XBEAM } \\ 1 . & .00000 & 19.23001 \\ 2 . & .45000 & 19.19683 \\ 3 . & .51000 & 17.18687 \\ 4 . & .53500 & 15.54349 \\ 5 . & .59500 & 13.55692 \\ 6 . & .79500 & 13.16546 \\ 7 . & 1.58500 & 11.63427\end{array}$

YBEAM

19.71301

19.70407

21.83617

23.64474

24.68565

17.00043

13.36172
ALPHAX

.16400

.15283

126.37660

114.22900

2.97254

2.87683

2.49878
BETAX

41.35590

41.21333

33.04173

27.01017

20.55420

19.38432

15.13759 
Data amplop transpor berkas untuk susunan eksperimen PIXE:

Data Gambar 5a.

\begin{tabular}{rrrrrr} 
No. & LENGTH & XBEAM & YBEAM & ALPHAX & \multicolumn{1}{c}{ BETAX } \\
1. & .00000 & 19.23001 & 19.71301 & .16400 & 41.35590 \\
2. & .45000 & 19.19683 & 19.70407 & .15283 & 41.21333 \\
3. & .51000 & 16.84733 & 22.21262 & 144.25330 & 31.72266 \\
4. & .53500 & 14.93208 & 24.34679 & 127.91260 & 24.93154 \\
5. & .59500 & 12.15534 & 26.08502 & 24.45052 & 16.52420 \\
6. & .79500 & 8.55941 & 20.34243 & 17.20234 & 8.19343 \\
7. & .98500 & 5.14880 & 14.88734 & 10.31697 & 2.96477 \\
8. & 1.64473 & 7.53098 & 4.33051 & -10.93339 & 6.34283 \\
9. & 1.83473 & 10.00000 & 10.00000 & -14.54437 & 11.18373 \\
10. & 2.04473 & 15.62028 & 13.31796 & -74.72096 & 27.29091 \\
11. & 2.14473 & 19.89711 & 13.35728 & -95.18291 & 44.28134 \\
12. & 2.35473 & 26.41353 & 14.93453 & -53.63391 & 78.03345 \\
13. & 2.85473 & 35.49120 & 22.38635 & -72.08816 & 140.91780
\end{tabular}

Data Gambar 5b :

\begin{tabular}{rrrrrr} 
No. & LENGTH & XBEAM & YBEAM & ALPHAX & \multicolumn{1}{c}{ BETAX } \\
1. & .00000 & 19.23001 & 19.71301 & .16400 & 41.35590 \\
2. & .45000 & 19.19683 & 19.70407 & .15283 & 41.21333 \\
3. & .51000 & 16.84733 & 22.21262 & 144.25330 & 31.72266 \\
4. & .53500 & 14.93208 & 24.34679 & 127.91260 & 24.93154 \\
5. & .59500 & 12.15534 & 26.08503 & 24.45007 & 16.52374 \\
6. & .79500 & 8.55937 & 20.34250 & 17.20277 & 8.19352 \\
7. & .98500 & 5.14873 & 14.88747 & 10.31689 & 2.96468 \\
8. & 1.64473 & 7.53106 & 4.33019 & -10.93334 & 6.34294 \\
9. & 1.83473 & 10.00005 & 9.99963 & -14.54403 & 11.18366 \\
10. & 2.04473 & 8.67866 & 21.36268 & 24.01773 & 8.42324 \\
11. & 2.14473 & 6.20491 & 29.90413 & 17.15783 & 4.30579 \\
12. & 2.35473 & 3.26519 & 32.55512 & 1.93734 & 1.19233 \\
13. & 2.85473 & 1.50000 & 1.50000 & -.05594 & .25163
\end{tabular}


Data Gambar 5c.

\begin{tabular}{rrrrrr} 
No. & LENGTH & XBEAM & YBEAM & ALPHAX & \multicolumn{1}{c}{ BETAX } \\
1. & .00000 & 19.23001 & 19.71301 & .16400 & 41.35590 \\
2. & .45000 & 19.19683 & 19.70407 & .15283 & 41.21333 \\
3. & .51000 & 16.84733 & 22.21262 & 144.25330 & 31.72266 \\
4. & .53500 & 14.93208 & 24.34679 & 127.91260 & 24.93154 \\
5. & .59500 & 12.15534 & 26.08503 & 24.45007 & 16.52374 \\
6. & .79500 & 8.55937 & 20.34250 & 17.20277 & 8.19352 \\
7. & .98500 & 5.14873 & 14.88747 & 10.31689 & 2.96468 \\
8. & 1.64473 & 7.53106 & 4.33019 & -10.93334 & 6.34294 \\
9. & 1.83473 & 10.00005 & 9.99963 & -14.54403 & 11.18366 \\
10. & 2.04473 & 8.64583 & 21.40950 & 24.20184 & 8.35973 \\
11. & 2.14473 & 6.14369 & 30.00449 & 17.18329 & 4.22120 \\
12. & 2.35473 & 3.12499 & 32.59556 & 2.04004 & 1.09213 \\
13. & 2.85473 & 1.44549 & 1.00480 & -.32313 & .23367
\end{tabular}

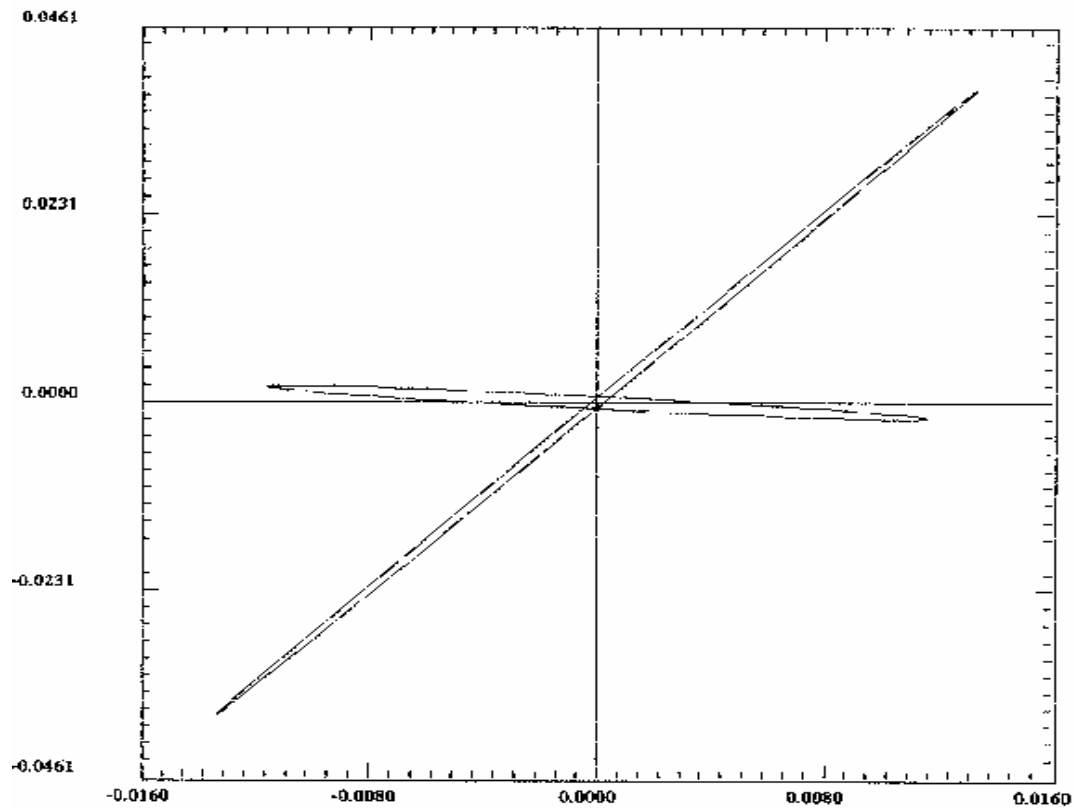

Gambar 1. Elips fase untuk eksperimen APNC 


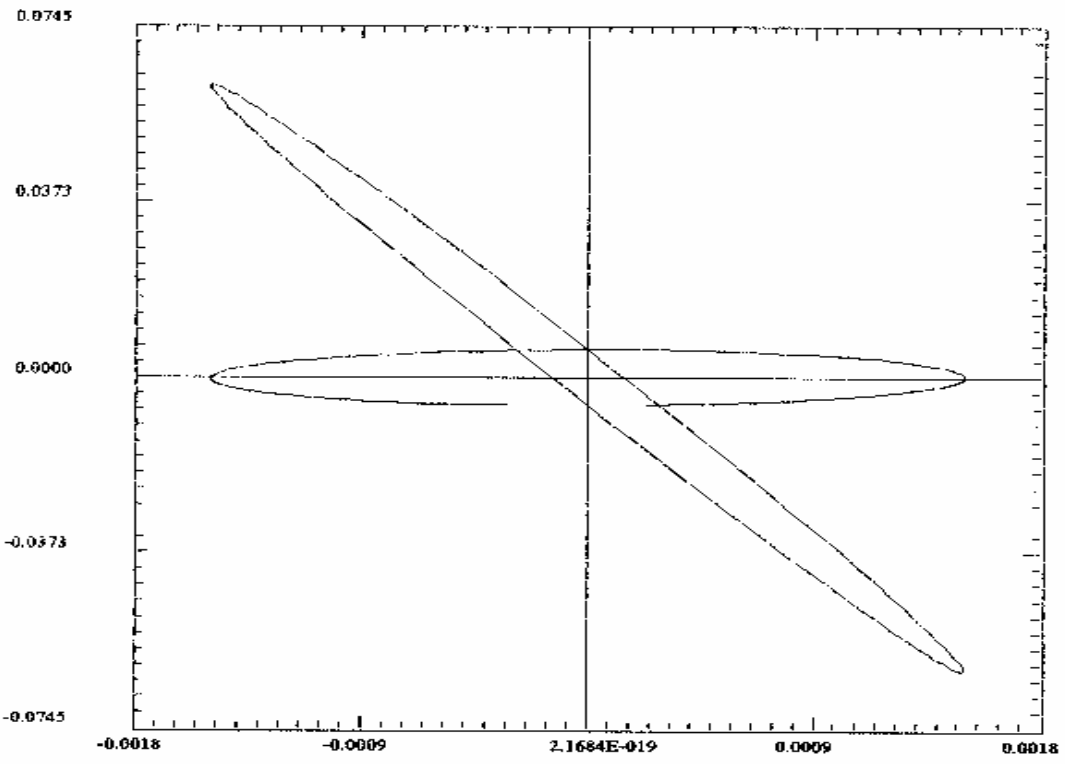

Gambar 2. Elips fase untuk eksperimen PIXE 